\title{
Biofuel and Economic Complexity in the Context of Global Competitiveness: Comparative Cases Between the United States, Brazil and China
}

\author{
Fernando Silva Lima ${ }^{1} \&$ Waldecy Rodrigues ${ }^{2}$ \\ ${ }^{1}$ Federal Institute of Education, Science and Technology of Maranhão (IFMA) - Carolina Advanced Campus, City \\ of Carolina, Maranhão State, Brazil \\ ${ }^{2}$ Regional Development, Federal University of Tocantins (UFT), City of Carolina, Maranhão State, Brazil \\ Correspondence: Fernando Silva Lima, PhD, Regional Development, Federal University of Tocantins (UFT), \\ Federal Institute of Education, Science and Technology of Maranhão (IFMA) - Carolina Advanced Campus, Rua \\ Imperatriz, City of Carolina, Maranhão State, Brazil.
}

Received: June 27, 2021

Accepted: July 23, 2021

Online Published: November 8, 2021

doi:10.5430/ijba.v12n6p36

URL: https://doi.org/10.5430/ijba.v12n6p36

\begin{abstract}
Abstratct
The present study aims to carry out an international analysis of the biofuels sector, from the United States, Brazil and China, in order to verify how countries have dealt with strategies for adding technology and value to the sector. The methodology of this study is focused on the analysis of data on the economic complexity of the biofuels sector, relating production and innovation indicators, from a quantitative and qualitative point of view. Very clear situations are evidenced in terms of international perspectives for the evolution of the biofuels sector among the countries selected in this study. The United States is a world leader in the production of biofuels and also increases its leadership in the technological domain through the generation of patents in Brazil, which is also a major international competitor, however, a less complex sector. In the era of patents, China, despite hardly appearing as a major international producer, has been investing heavily in the generation of new technologies, also betting on the complexity of the sector.
\end{abstract}

Keywords: development, global, biofuel, renewable sources

\section{Introduction}

Biofuel is a product derived from organic vegetable or animal material (biomass) and converted into renewable energy. In the case of ethanol production, it can be obtained from sugar cane, corn, beet, cassava, potatoes and, in the case of biodiesel production from vegetable oils (sunflower, castor bean, soybean, babassu and other oilseeds) ), as well as alternative raw materials, such as animal fat (marrow) or frying (RIBEIRO 2013; 2014).

Biofuel emerged in the 19th century, Goettemoeller \& Goettemoller (2007), in his research on biofuel from ethanol production, recall that the German engineer Nikolas Otto, in 1860, used alcohol as fuel for one of his combustion engines. "Otto" cycle. Even in a scenario of heavy taxes, in North America, Henry Ford designed his first car, a quadricycle, powered exclusively by ethanol in 1896. Regarding biofuel from the production of biodiesel, it is worth remembering that in 1900 it was presented a Rudolf Diesel engine at the Universal Exhibition in Paris, running on peanut oil (MAIA \& FEITOSA, 2009).

We live in a time in the economy where the most efficient use of natural resources has become strategic and competitive, especially those coming from the Sun and photosynthesis processes, in which the production of biofuels stands out. Because, as Silva, et al (2013) points out, fossil fuels are finite, non-renewable sources and responsible for considerable $\mathrm{CO} 2$ emissions into the atmosphere, so ethanol and biodiesel are identified as viable alternatives to provide clean and renewable energy .

The environmental advantages of biofuel production and use are fundamentally associated with the reduction of greenhouse gases. It is due to climate change and the environmental imbalance that the world is suffering, that many countries have recognized the importance of breaking the dependence on fossil fuels through the adoption of policies 
for the production of clean and renewable energy that meets market demands (ANTONIOSI AND MAINTINGUER, 2016).

For Masiero and Lopes (2008), in this market still in formation, Latin American countries and the United States are seen as potential suppliers of ethanol and biofuels, however Asian countries and India despite having less soil availability for cultivation recently invested in technologies for second and third generation biofuels.

Based on the above, the central question of this study is: how can countries make better use of economic alternatives by adding value and technology in the production of biofuels? Which countries are concerned with this technological evolution applied to the economic complexity of the sector?

It is based on this questioning that the general objective of this study is to carry out an international diagnosis of the biofuels sector, from the United States, Brazil and China, in order to verify how the countries have treated the strategies of adding technology and value to the sector. Specifically, it is intended to analyze the installed capacity of biofuel in relation to production in the international context; evaluate biofuel in relation to innovation and technology and; understand the economic complexity of biofuel in selected countries.

\section{Methodological Procedures}

The methodological procedures adopted to achieve the objectives proposed in this study are divided into 4 stages: a) selection of the study area; b) data collection and c) data analysis and interpretation.

\subsection{Selection of the Study Area}

The countries chosen for the most specific study were the United States, Brazil and China, as they are the largest producers and consumers of biofuels and, at the same time, those with the most patent registrations in biofuels in the world (IEA, 2006), (BP , 2019), IRENA (2020).

\subsection{Data Collect}

Initially, a review of the literature on biofuels was carried out. Then, the data were collected on the Institutions Portal: International Limited (BP) and International Renewable Energy Agency (IRENA). Then, the data were transferred, tabulated and converted to graphics.

\subsection{Data Analysis and Interpretation}

After elaborating the graphs, the data were analyzed to understand the sector in terms of production, installed capacity and registered patents, in order to understand in a panoramic way the dynamics of the sector from the conceptions of the theory of economic complexity.

For Hausmann (2009), the theory of economic complexity not only demonstrates that the volume of products produced in a country is associated with the way they are manufactured, but also shows that knowledge in production is a differential in rich countries, because it occurs more intensely therefore, the more knowledge there is, the more complexity there will be. In this case, complexity plays a key role in the sophistication of a product.

Currently, there are two basic concepts for assessing whether a country is economically complex: the ubiquity and diversity of products found on its export agenda (GALA, 2017). For the author, if an economy is capable of producing rare, complex and non-ubiquitous goods, there is an indication that the country has a sophisticated productive fabric.

It is understood that non-ubiquitous goods are divided between those that have a high technological content and, therefore, are difficult to produce, such as airplanes and those that are very scarce in nature, such as diamonds (GALA, 2017).

The term sophistication extends not only to the production of biofuels, but also to the manufacture of hybrid and electric cars, as it is in this process that complex products are created with wide integration between companies that need a multitude of suppliers and producers, inside and outside of the producing country that integrates the production process, called global value chains. In general, high connectivity products are complex and low connectivity products are not complex; in this case, oil extraction is not complex, but, on the other hand, the machines on which the fuel is produced are quite complex (GALA, 2017).

It is considered that the economy in general, and a sector in a specific way, only advances structurally, with the evolution of its level of economic complexity, its perspective of connection with new complex products in space. Thus, there is a sustained process that can allow structural variation in GDP per capita, in exports and in the generation of sophisticated jobs and income, with the demand for qualified labor. Thus, the economic complexity of 
sectors of the economy explains how per capita income has consistent historical leaps, leaving for example a region with medium income to high income (HAUSMANN, et al., 2013).

Based on the theory of economic complexity, the data collected on the production of biofuels, their industrial transformation and also the level of innovation of the sector in the selected countries (Brazil, USA and China) were related. Subsequently, information was collected on the technological evolution in each of these countries to deepen the comparative analysis of the data.

\section{Results and Discussion}

It is observed by the world production of biofuels in tons that almost $50 \%$ of the production of biofuels is concentrated in the United States, almost 25\% concentrated in Brazil and 5\% less concentrated in China. It is observed that Brazil, in addition to producing more biofuel than China, surpassed several rich countries, among them: Germany, Holland, United Kingdom. See Figure 1.

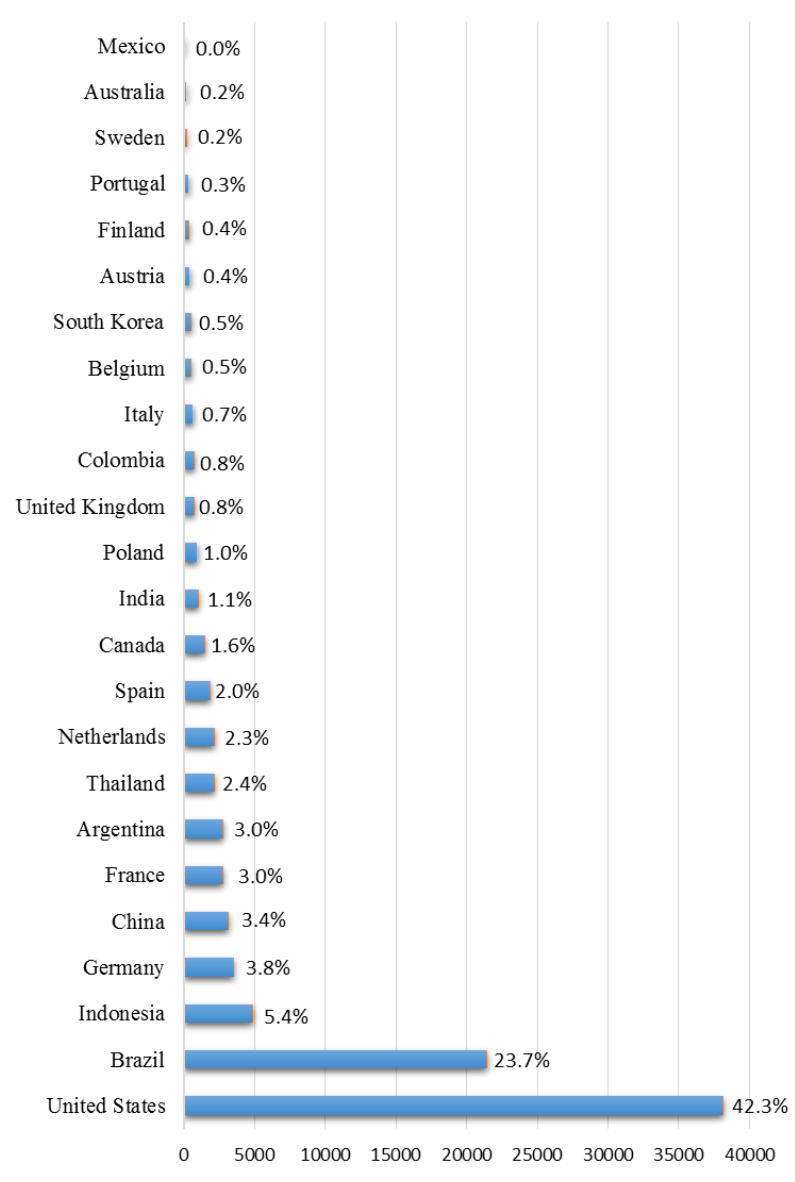

Figure 1. World biofuel production in tons in 2018

Source: BP International Limited (2020). Adapted by the author

Brazil's position in relation to biofuel production compared to other countries is explained by the fact that it is the largest producer of sugarcane ethanol in the world, but, in total production, it lags behind the United States, which uses corn. However, the ethanol production technology in Brazil is fully mature, still allowing for some productivity gains in the agricultural area and little in the industrial area; there are varieties of genetically modified sugarcane that would allow great reductions in production costs, although they cannot be used due to the long release process (LEITE AND LEAL, 2007). 


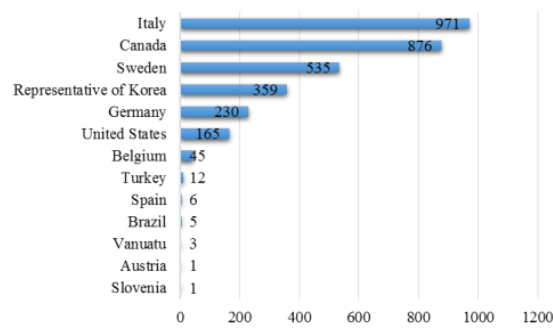

Figure 2. Installed capacity of liquid biofuels including biofuel liquids and colored biofuels in megawatts (MW) 2018

Source: BP International Limited (2020). Adapted by the author

Figure 2 shows that Brazil, although it has a lower production capacity than several countries such as Spain, Turkey and Belgium, it is observed that it is currently the second largest biofuel producer in the world, trailing behind in the production ranking only for the United States.

In the same vein, although it is perceived that the United States is the largest producer of biofuel in the world, it was noted that the installed production capacity in the country is less than the installed production capacity of biofuel in Germany, Korea, Sweden, Canada and Italy.

Thus, it was observed that there is practically no installed capacity for the production of biofuels in China, which can be explained by studies by Zhou and Thomson (2009), that the Chinese biodiesel industry is yet to be quite developed because, the sector it has a small installed capacity of 300,000 tons and biodiesel is produced from animal waste from fats and vegetables, considered to be low quality sources.

Although in Figure 2 China does not appear in the ranking of installed capacity for the production of biofuels, it is the fifth largest producer of biofuels in the world, surpassing Italy because, according to IRENA (2014), the demand for production and heating of biofuels in industrial sectors and heating represent $45 \%$ of total demand.

There is a conception that part of this demand is linked to the transport sector due to the technology options in liquid biofuels and electric mobility that resulted in twice the production of ethanol between 2005 and 2012 , reaching a total of 2.5 billion liters ( CNREC, 2013a); (IRENA, 2014).

Although biodiesel production in China is quite limited, with around 0.5 million tonnes out of a total production capacity of 3 million tonnes in 2009, and production levels remain stagnant today (QIU et al., 2012; USDA, 2012; CNREC, 2013a).

To better understand the competitive conditions of biofuel between countries, it is relevant to analyze the international behavior of biofuel in relation to the generation of patents, as well as the specific technological innovations carried out in the sector, as shown in Figure 3.

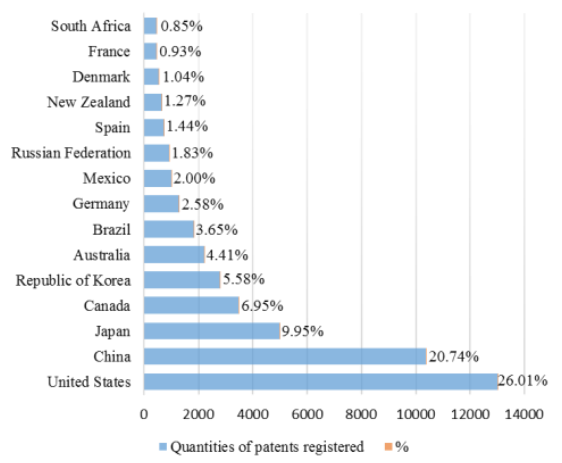

Figure 3. Number of biofuel patent registration in the world until 2016

Source: IRENA - International Renewable Energy Agency (2019). Adapted by the author 
Based on Figure 3, it can be said that although China is considered the fifth largest producer of biofuel until 2018, it is important to consider that the country in 2016 was the second largest country in the world in terms of registration of renewable patents, second only to the United States that even in the same year there were 13,177 patents registered, $26 \%$ of the total renewable patents in the world.

The United States, in recent years, has seen an increase in the number of Electric Vehicles sold. In 2011, for example, the country announced a goal that aimed to facilitate a production capacity of 1 million electric vehicles in the USA by 2015 (US DoE, 2011a). However, in 2014, the study by Navigant (2014) already projected that the global market for battery electric vehicles (BEVs) would reach only 350,000 in 2014 and only $4 \%$ of all new passenger cars sold globally in 2022 will be fully electric .

The economy of electric vehicles is improving, and efforts in states like California to promote zero-emission vehicles could result in a rapidly expanding market for electric mobility. However, recent trends still show that the majority of electric vehicles sold are pluggable hybrid electric vehicles (PHEVs) and battery-powered non-electric vehicles (Cleantechnica, 2014b).

Based on this, Figure 4 is presented, on the evolution of patents between the countries analyzed in this study.

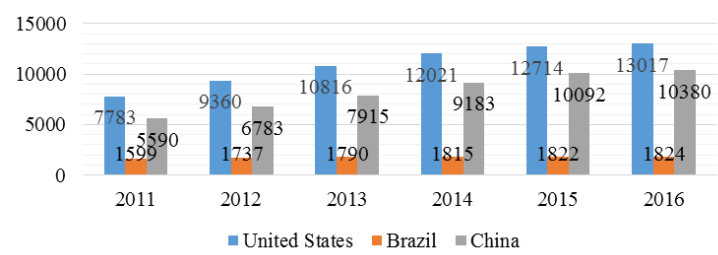

Figure 4. Evolution of patents among the main biofuel producers in the world between 2011 and 2016

Source: IRENA - International Renewable Energy Agency (2019). Adapted by the author

Based on what was presented about the evolution of patent registration and its specificities, the issue of the economic complexity of biofuel in the United States, Brazil and China can be demonstrated from the comparative indicators in Figure 5 .

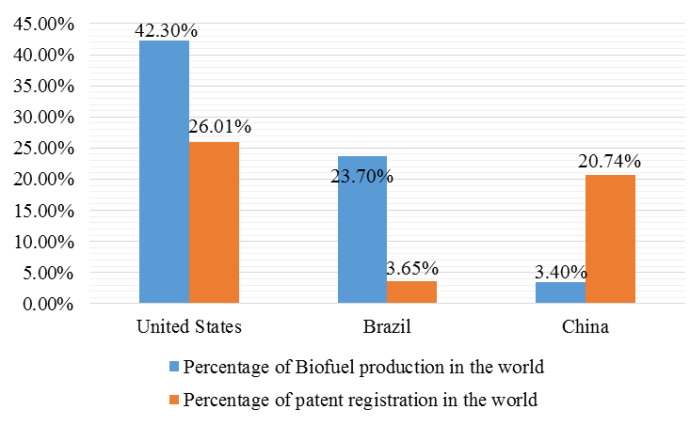

Figure 5. Economic complexity of biofuel between countries

Source: IRENA - International Renewable Energy Agency (2019) and BP International Limited (2019). Adapted by the author

It is noticed that very clear situations are evidenced in terms of international perspectives for the evolution of the biofuels sector among the countries selected in this study. First, the USA is a world leader in the production of biofuels and also bases its leadership in the technological domain through the generation of patents, which can be considered a country with a complex sector in the definitions used in this work. Brazil, which is also a major international competitor, leading mainly in lower costs, has a less complex sector, with less generation of patents. 
Particularly noteworthy is China, which despite not being a major international producer, has been investing heavily in the generation of new technologies, also betting on the complexity of the sector, but in conditions that differ from the USA, in the field of production.

In this case, from the United States GSR Solutions stands out as a privately owned American institution that has developed several technologies, including GSR-AD-BOLT, which is a technology that benefits farms, industries and municipalities that operate recovering anaerobic digesters efficiently from nitrogen and phosphorus from digested effluents, further reducing the Biochemical Oxygen Demand (DBO) of anaerobically treated effluents, allowing the production of evaluated by-products, including changes in soil, fertilizers and fuels (GSR SOLUTIONS LLC, 2019).

GSR Solutions recently patented an algae cultivation system that seeks to provide an economical alternative to the production of algae biomass from fertilizers, feed and biofuels to recover nutrients from wastewater for the production of evaluated by-products, recycled water and energy production alternative and renewable. (KRIVOV, 2014).

Another institution that has received worldwide patent recognition over the years is Energy Integration, also based in the United States, of which some points are important to highlight. This institution was the first to develop a technology for the production of corn ethanol in the late 1970s, with a capacity of 400,000 gallons per year. Its first patent was issued in 1982, a few years later, in 1985, a commercial scale dry mill ethanol plant was built that incorporates the technology with an annual production capacity of approximately 15 million gallons per year (ENERGY INTEGRATION INC, 2019).

However, in 2018, Energy Integration patented a technology that provides processes and systems to compress distillation vapors and recover heat from condensation by compressing steam and deriving mechanical, thermal and electrical energy from a combined heat and power system, maintaining capacity original operational plan. The plant's existing distillation system, steam generation and electrical demand determine the basis of the modernization system design, aiming at an ideal combination of energy use, energy cost and environmental impact. Steam compression (by mechanical steam recompression and / or thermal steam recompression) minimizes total energy use. Optionally, the combined heat and energy provide a means of converting energy between fuel, electricity (CRAWFORD \& SCHAFER, 2018).

In addition to these institutions, there are Wisconsin Alumni Res, Zea10 Llc, Manta Biofuel, Marshall Maximilian Davis and Nat Tech \& Eng Solutions Sandia, among others seeking innovation and technology through patents recently registered in the United States, which is why there is a conception of that the United States is, and can remain, complex due to the fact that there are still institutions focused on technology development and innovation.

In turn, China, despite occupying the 5th position in terms of biofuel production, has become complex, occupying the second place in the world in number of patents, unlike Brazil which, in the production of biofuel, occupies the 2nd place in production, but in the patent registration ranking it is the seventh, which indicates that the sector is not complex, since it represents $3.65 \%$ of the patents in the world, that is, in terms of economic complexity, neither does India advanced. It is from this that the first, second, third and fourth generation of biofuel are discussed, so that this change in classification in terms of technology and innovation can be understood.

According to Lee and Lavoie (2013), first generation biofuels include ethanol and biodiesel and are directly related to a biomass that is more than often edible. Ethanol is generally produced from the fermentation of C6 sugars (mainly glucose) using classical yeast strains or GMOs, such as Saccharomyces cerevisiae. Only a few different raw materials, mainly sugar cane or corn, are actually used for the production of first generation bioethanol. Other, more marginal raw materials used to produce first generation ethanol include, among others, whey, barley, potato waste and sugar beet. Sugarcane is a common raw material for the production of biofuels, Brazil being one of the leading countries in its use. The process that allows the production of ethanol from sugarcane is quite simple. Sugarcane is crushed in water to remove sucrose, which is purified to produce raw sugar or ethanol.

It is understood that, in the study by Lee and Lavoie (2013), it is clear that the production of ethanol from sugar fermentation is part of the first generation of biofuel, in which there may be little use of sophisticated machines and equipment to produce it. However, complexity cannot be ruled out based on this study, because in countries that have invested in technology and innovation such as the United States, which represents $26 \%$ of the world's patents, there may be complexity in the exports of these products.

Biodiesel is the only other biofuel produced on an industrial scale. The production process of this biofuel is very different from ethanol, as it can be considered a chemical process. Obviously, it uses biomass (plants and oil seeds), but the process itself is based on extracting the oils and converting them into biodiesel, breaking the bonds that link 
the fatty acids of the long chain to the glycerol, replacing it with methanol in a process called transesterification (LEE and LAVOIE, 2013).

Unlike ethanol, the production of biodiesel is more dependent on technology and innovation, since the extraction of essential oils to convert them into biofuel can generate sophistication not only in exports, but also in the production of these products. For Lee and Lavoie (2013), second generation biofuels are defined as fuels produced from a wide variety of raw materials, but not limited to non-edible lignocellulosic biomass, in which it is generally more complex to convert and their production depends on new technologies, as it is linked to the commodities market; therefore, the cost of converting the original raw material into the final product must be as low as possible to maintain profitability.

This generation is believed to insert underdeveloped and developing countries that, over the years, have invested little in technology and innovation, as public and private institutions expand the resources available to the biofuels sectors through new credit lines, since to produce biofuel from new raw materials, it is necessary to acquire new machinery and technological equipment.

The most accepted definition for third generation biofuels are fuels that would be produced from algae biomass that has a very different growth yield compared to classic lignocellulosic biomass (BRENNANA and OWENDEA, 2010). The lipids obtained from algae can be processed by transesterification using the biodiesel process described above or they can be subjected to hydrogenolysis to produce alkane with kerosene grade suitable for use as aviation fuel (TRAN et al., 2010).

There is a conception that the expansion of the patent register shows that countries are seeking economic complexity in the sector, although the patent process is developing slowly in countries like Brazil and India, that is, similar countries, in terms of investments in technology. and innovation, who sought to invest in patents, is certainly producing aviation fuels from algae, which is called the third generation.

For Pandey and Kumar (2017), the fourth generation of biofuels is still under development and none of the practically synthesized compounds have been tested. To date, it is the most promising and referred to as the most advanced generation of biofuels. The theoretical concepts on which the principles of the fourth generation are established are: development of genetically modified plants that will consume more dioxide (CO2) from the atmosphere. Combination of oilseeds and algae plants to stimulate a species of cross-genetics of high yield and success. For the authors, at the moment, only a few companies are working on it, the most popular being Craig Ventor's Synthetic Genomics, which is prototyping microorganisms that can directly produce fuel from carbon dioxide (CO2). By 2050, this generation is expected to be fully developed and to play an important role in the world's energy sector. Thus, it can be said that countries such as the United States, Brazil and China have evolved, but in each generation of biofuel, this evolution has become more complex, since it requires, from the registration of patents, more investments in technology and innovation.

\section{Conclusion}

Based on the diagnosis, it is concluded that biofuel in terms of economic complexity is due to the particularities of each country in relation to the installed production capacity and the way they invest in technology and innovation. In Brazil, for example, it is difficult to believe in an economic complexity linked to the sector, as there is little investment in technology and innovation, considering that, at the moment, the country has about $3 \%$ of the world's registered patents related to biofuels.

Unlike the United States, which believes that the biofuels sector can be economically complex, as it is one of the countries that most invests in technology and innovation, responsible for $26 \%$ of the patent registration and high connectivity; therefore, it was found that in this country there is economic complexity in this sector.

In relation to China, there is the concept that it is one of the world's leading producers of biofuels, which has been growing in the sense of economic complexity when one realizes that $26 \%$ of patents registered in the world are Chinese, a similar proportional increase for the United States that consequently, it can reflect in the field of international competitiveness as a whole.

Thus, this research ends up answering the central question highlighted in the introduction of this study on how countries can better use the economic alternatives that add value and technology in the production of biofuels, pointing out that the alternative is to seek technological innovations, more sophisticated products and, at the same time. time, products more connected to the value chain.

Finally, this study revealed that the United States has been concerned with the evolution of technology applied to the economic complexity of the sector, since more than a quarter of global biofuel patents are concentrated in the USA. 
However, China also has the same concern, as it has advanced a lot in the direction of innovation, which ends up contributing to the sustainable economy for future generations.

\section{References}

Antoniosi, L., \& Maintinguer, S. I. (2016). Políticas públicas e dinâmicas de mercado aplicadas à produção de biodiesel no brasil: uma visão do marco regulatório e do selo combustível social. Revista Brasileira Multidisciplinar-ReBraM, 19(1).

BP - International Limited. (2019). BP statistical review of world energy (68th ed.).

Brasil. Lei $\mathrm{n}^{\circ}$ 9279, de 14 de maio de 1996. (1996). Regula direitos e obrigações relativos à propriedade industrial. Diário Oficial da União, Brasília. Retrieved May 22, 2015, from http://www.planalto.gov.br/ccivil_03/Leis/L9279.htm

Brennana, L., \& Owendea, P. (2010). Biofuels from microalgae - A review of technologies for production, processing, and extractions of biofuels and coproducts. Renewable Sustainable Energy Rev., 14, 557-577.

Cleantechnica. (2014b). US electrified vehicle sales update, 3 July 2014. Retrieved June 26, 2020, from cleantechnica.com/2014/07/03/us-electrified-vehicle-sales-update-nissan-1-ford-fusion-energi-2

Cnrec. (2013a). 2012 China Renewable Energy Outline, December 2013, CNREC, Beijing, China.

Crawford, L. A., \& Schafer, W. B. (2016). Energy-efficient systems including vapor compression for biofuel or biochemical plants. Applicant(s): Energy Integration Inc.

Energy Integration Inc. (2019). Optimizing energy recovery. Retrieved December 26, 2019, from http://energyintegrationinc.com/index.html

Gala, P. (2017). Complexidade econômica: uma nova perspectiva para entender a antiga questão da riqueza das nações. Contraponto: Centro Internacional Celso Furtado de Políticas para o Desenvolvimento (1st ed.). Rio de Janeiro, 2017.

Goettemoeller, J., \& Goettemoller, A. (2007). Sustainable ethanol. Prairie Oak Publising, Maryville, Misouri, 2007.

GSR Solutions Llc. (2019). Managing excessive waste nutrients is a colossal problem!. Retrieved December 23, 2019, from https://www.gsrsoln.com/whatwedo.html

Hausmann, R., \& Hidalgo, C. (2009). The building blocks of economic complexity. Proceedings of the National Academy of Sciences of the United States of America, 106(26), 10570-10575.

Hausmann, R., et al.. (2013). The atlas of economic complexity: mapping paths to prosperity (2nd ed.). Cambridge: MIT Press. Retrieved December 15, 2019, from http://www.tinyurl.com/y67m6n72

IEA. World Energy Outlook. (2006). Chapter 14, The Outlook for Biofuels, OECD Publications, Paris. 2006.

IRENA - International Renewable Energy Agency. (2019). About IRENA. Retrieved September 17, 2019, from https://www.irena.org/aboutirena

IRENA - International Renewable Energy Agency. (2019). Advanced biofuels. What holds them back?. International Renewable Energy Agency, Abu Dhabi, 2019.

IRENA. (2014). Renewable Energy Prospects: China, REmap 2030 analysis. IRENA, Abu Dhabi. Retrieved June 25, 2020 ,

from https://www.irena.org/-/media/Files/IRENA/Agency/Articles/2014/Dec/IRENA_REmap_China_report_2014.pd f?la=en\&hash=396185747F6EB44CAED09039797DE0B200EE607E

IRENA. (2020). Renewable capacity statistics 2020 International Renewable Energy Agency. IRENA, Abu Dhabi.

Krivov, A. D. (2014). Systems and methods of producing compositions from the nutrients recovered from waste streams. Applicant: Gsr Solutions Llc.

Lee, R. A., \& Lavoie, J. M. (2013). From first- to third-generation biofuels: Challenges of producing a commodity from a biomass of increasing complexity. Animal Frontiers, 3(2), 6-11. https://doi.org/10.2527/af.2013-0010

Leite, R. C. de C., \& Leal, M. R. L. V. (2007). O Biocombustível No Brasil. Revista: Novos Estudos 78, Julho 2007. Retrieved June 17, 2020, from https://www.scielo.br/pdf/nec/n78/03.pdf

Maia, A. A., \& Feitosa, V. N. (2009). Histórico dos biocombustíveis no Brasil. Revista de Direito Ambiental, 53, 7-23. 
Masiero, G., \& Lopes, H. (2008). Etanol e biodiesel como recursos energéticos alternativos: perspectivas da américa latina e da Ásia. Rev. Bras. Polít. Int., 51(2), 60-79. Retrieved October 2, 2019, from http://www.scielo.br/pdf/rbpi/v51n2/v51n2a05.pdf

NAVIGANT. (2014). Navigant Research forecasts new EV global sales of 246,000 units in 2014; 10 predictions for the year, Navigant Research, 8 January 2014. Retrieved June 25, 2020, from www.greencarcongress.com/2014/01/20140108-navigantev. html

Pandey, R., \& Kumar, G. (2017). A comprehensive review on generations of biofuels: current trends, development and scope. International Journal on Emerging Technologies, 8(1), 561-565. Retrieved December 19, 2019, from https://www.researchtrend.net/ijet/pdf/121-S-857a.pdf

Qiu, H., et al.. (2012). Liquid biofuels in China: Current status, government policies, and future opportunities and challenges. Renewable and Sustainable Energy Reviews, 16, 3095-3104.

Ribeiro, R. A. (2013). Estado e biocombustíveis: uma parceria para o desenvolvimento?. Ponto de Vista, (8). Retrieved May 5, 2014, from https://www.academia.edu/13429208/Estado_e_Biocombust\%C3\%ADveis_no_Brasil_uma_parceria_para_o_d esenvolvimento

Ribeiro, R. A. (2014). Inserção internacional e energia: a política externa de Lula para biocombustíveis. Retrieved August 5, 2019, from http://www.funag.gov.br/ipri/btd/index.php/10-dissertacoes/3822-insercao-internacional-e-energia-a-politica-ex terna-de-lula-para-biocombustiveis

Silva, A. T. B. D., et al.. (2013). Cenários prospectivos para o comércio internacional de etanol em 2020. Revista de Administração, 48(4), 727-738. Retrieved September $18, \quad 2019$, from http://www.scielo.br/pdf/rausp/v48n4/08.pdf

Tran, N., Bartlett, J., Kannangara, G., Milev, A., Volk, H., \& Wilson, M. (2010). Catalytic upgrading of biorefi nery oil from micro-algae. Fuel, 89, 265-274.

USA - United States of America, Department of energy-DoE. (2011a). One million electric vehicles by 2015, US DoE. Washington, D.C. Retrieved June 25, 2020, from <www1.eere.energy.gov/vehiclesandfuels/pdfs/1_million_electric_vehicles_rpt.pdf

USDA (US Department of Agriculture). (2012). China-People's Republic of Biofuels. Annual Gain Report Number 12044, 9 July 2012, USDA Foreign Agricultural Service, Global Agricultural Information Network. Washington, D.C. Retrieved June 25, from http://gain.fas.usda.gov/Recent\%20GAIN\%20Publications/Biofuels\%20Annual_Beijing_China\%20-\%20People s\%20Republic\%20of_7-9-2012. pdf

Zhou, A., \& Thomson, E. (2009). The Development of Biofuels in Asia. Applied Energy, 2009. Retrieved June 25, 2020 ,

from https://www.scielo.br/scielo.php?script=sci_nlinks\&ref=000203\&pid=S0034-7329201100020000500037\&lng= en

\section{Copyrights}

Copyright for this article is retained by the author(s), with first publication rights granted to the journal.

This is an open-access article distributed under the terms and conditions of the Creative Commons Attribution license (http://creativecommons.org/licenses/by/4.0/). 